\title{
NON SECULARIZATION OF MARRIAGE LEGAL PROCEDURE BASED ON BELIEF IN ONE ALMIGHTY GOD IN INDONESIA
}

\author{
Burhanudin'; Solikhah ${ }^{2}$; Luthfiyah Trini Hastuti ${ }^{3}$ \\ 1,2,3Faculty of Law Universitas Sebelas Maret \\ Email: burhanudin60@gmail.com; Solikhahfh@gmail.com; \\ luthfiyahth@gmail.com
}

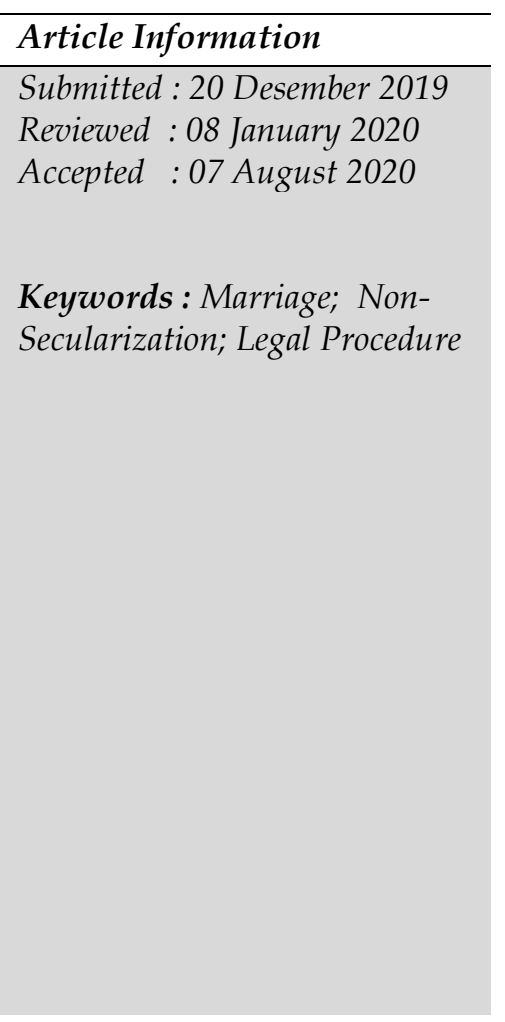

\begin{abstract}
When disputing in court, non-Muslim citizens use positive laws established by the state that do not involve their religious beliefs. Philosophically, this is on the contrary to the constitution, which states that the country is based on belief in one Almighty God. Moreover, in every decision, judges are formally required to begin with "For the sake of the one Almighty God." This phenomenon may be the result of cultural and/or structural factors that require a research study. This research is normative legal research to devise models of religious legal formulation in the legal system in Indonesia. The results of the study illustrate that changing secular marriage law to religious marriage law is possible through formal procedural rules and substantial material rules. In the initial stages, efforts should be made to change the formal procedural arrangement stage using a procedure to examine, adjudicate, and decide a case. Before deciding on a divorce case, the religion of the disputing parties needs to be involved by (1) appointing a judge who is of the same religion as the disputing parties to examine, adjudicate, and decide the case; (2) requiring judges to present expert witnesses from religious leaders of the disputing parties. This is very important because religion is a truth system based on belief and not all religious beliefs can be rationalized.
\end{abstract}

\section{Introduction}

The Indonesian people were in the grip of Dutch colonialism for three and a half centuries. The Netherlands, in reality, did not only colonize the economy, but also colonize the field of law. The enactment of Dutch law in Indonesia, which was based on the principle of concordance and various efforts to get rid 
of the original Indonesian law which is religious, is a concrete evidence that is indisputable. As a result, Dutch secular law dominates law in Indonesia. Western legal logic, concepts, and legal theories dominate legal thinking in Indonesia.

The proclamation of independence is a statement of the Indonesian people to have an independent state free from colonialism. It means that normatively, the Proclamation of Independence on August 17, 1945 is a statement of independence of the Unitary State Republic of Indonesia. Independence in the state covers all aspects of life: social, economic, cultural, political, and legal.

A state based on belief in one Almighty God is the choice of Indonesian people in the life of the people and nation. This is an affirmation of ideal, that Indonesia is different from Western and American countries that embrace secular ideology, which separates religious and state affairs (Tedjomurti, K. T, 2019: 199). This is also an affirmation that Indonesia is different from western civilization which is materialistic in nature (Mahmoud Mohammed Taha, 1996: 75).

The rule of law based on belief in one Almighty God is a form of affirmation of independence in the field of law in the Republic of Indonesia. Therefore, normatively, the laws that will be made and will be applied in Indonesia are laws based on belief in one Almighty God. Thus, efforts to make and enforce laws based on this belief in the field of marriage have been prepared in the Law Number 16 of 2019 on Amendment of Law Number 1 of 1974 on Marriage.

The marriage law for Muslim citizens in Indonesia is the Islamic marriage law. Marriage law for Catholics is Catholic law. The marriage law for Christian citizens is Christian law. The law for the Hindu citizens is the law of the Hindu 
religion. The law that applies to citizens of Buddhism is Buddhist law. The marriage law that applies to citizens who are Confucian is a Confucian law.

Efforts to establish marriage law based on religion as outlined by the 1945 Constitution in reality cannot yet be enforced by the country, except Islamic law that applies to Muslim citizens. Therefore, the study analyzes the problem of marriage law based on religion for citizens who are not Muslim, as stated in Article 2 paragraph (1) Law Number 16 of 2019 on Amendment of of Law Number 1 of 1974.

Third paragraph of the Preamble of the 1945 Constitution states that the independence is a blessing bestowed by Allah. It confirms that the independence of the Indonesian people is not only caused by the outward struggle of the people, but also the struggle under the grace of the Almighty God. Therefore, independence is God's grace. The fourth paragraph of the Preamble states that independence in the form of a state structure is based on Pancasila.

Indonesia is a country that is based on law, which means law is the fundamental basis of the life of the nation. It is normatively reaffirmed in Article 1 paragraph (3) of the third amendment to the 1945 Constitution.

The constitution has strongly outlined that the basis for state and law is belief in one Almighty God, which means Indonesia is a state of law based on belief in one Almighty God. Thus, the law governing the state affairs and the life of Indonesian people is a law based on belief in one Almighty God, which in this study is conceptualized as religious law.

Independence is the ideal of the Indonesian people initiated by the warriors and is realized by the grace of God. Independence is a means to realize the ideal of the nation (which is to become independent, united, sovereign, just, 
and prosperous). It can be realized by forming a country. The country carries out its duty to realize the ideal of the nation through the means of government. It means that the government is the frontline fighter to realize the ideal of independence. Therefore, the government as the executor of the constitutional duty of the state must be oriented to the politics of law based on belief in one Almighty God.

The constitutional provision regarding the state based on belief in one Almighty God, as determined under Article 29 paragraph (1) of the 1945 Constitution, is based on the textual awareness which the founding fathers formulated as a grace of Allah, which establish a constitutional basis that Indonesia is not a secular country that separates the country from God's religious affairs, unlike the basis for the formation of western countries. Although it refers to God in the Islamic religion, based on the willingness of the majority of Muslims which is initiated by the constitution formulators, it is determined that the country is based on belief in one Almighty God, not Islam.

The constitutional provision which states that the country is based on belief in one Almighty God is a form of country recognition of the existence of various religions adhered to by Indonesian citizens outside the majority religion. This recognition must be understood as an appreciation of the equal rights and obligations of citizens without discriminating their religions. The country gives freedom of religious followers to carry out their religious orders, as long as they do not interfere with followers of other religions. Likewise, every religion has an obligation in the country, namely the obligation to maintain the existence of the country as part of religious teachings, which is to be realized at the state level.

Article 29 paragraph (2) states that there is freedom of the citizens to worship according to religion and belief so that the state has the obligation to 
guarantee every citizen to do something and not to do something as regulated in the religion s/he believes. The state must not prohibit citizens who carry out their religious orders. Likewise, the state must not order citizens to do something that is prohibited by the teachings of the religion they hold and believe. The problem that arises then is the fact that non-Muslim citizens do not have a marriage law as determined in Article 2 paragraph (1) Law Number 16 of 2019 on Amendment of of Law No. 1 of 1974 on Marriage.

\section{Research Methods}

The research is normative legal research. It is used to devise models of religious legal formulation in the legal system in Indonesia based on Pancasila and the 1945 Constitution. The research is conducted by (1) knowing and analyzing the reasons why the marriage law based on religions other than Islam as determined in Law Number 16 of 2019 on Amendment of Law No. 1 of 1974 on Marriage has not become a law enforced in the court and (2) finding a procedural formulation model of marriage law enforcement for religions other than Islam in Indonesia based on belief in one Almighty God.

\section{Research Results and Discussion}

\section{A. Religion and the Republic of Indonesia}

Article 29 paragraph (1) of the 1945 Constitution states that a country based on belief in one Almighty God is a clear and fundamental constitutional affirmation that Indonesia is not a secular country. On the other hand, the fact that there is no certain religion stated in the 1945 Constitution indicates that Indonesia is not a country based on a particular religion. Therefore, the relationship between religion and the state can be explained with its relation to 
the paradigm that develops in political sociology, which are (Marzuki Wahid and Rumadi, 2003: 23):

\section{Indonesia is not a secular state}

Secularism is an ideology that separates real life from religious thoughts and influence. A secular state is a state that separates state affairs from religion. It means that state affairs must not be intervened by religion. In addition, religion must not interfere with political, economic, social, legal culture, and other aspects of the state reality. The state does not make religion a political instrument. Religion is a private affair of its believers.

Based on the ideology that separates religion and state, all religions have the same position, none of them is privileged. Then, the awareness of the use of religion for manipulation for political purposes is needed. It can be avoided if religion is kept away from political intrigues, including the use of religious symbols in the state structure ((Marzuki Wahid and Rumadi, Ibid).

Secular ideas also exist in the minds of Islamic scientists. One of the initiators was 'Aliy 'Abd ar-Raziq (1887-1966 AD), a Muslim scholar from Egypt. 'Abd al-Raziq in the book Al-Islam wa Ushul al-Hukm states that Islam does not take care of a state based only on religion. In Islam, there is no relation between religion and the governmental system of the caliphate (alKhulafa ar-Rashidin). Al-Khulafa ar-Rashidin is not a religious or Islamic political system, but an earthly system. 'Ali 'Abd ar-Raziq states that Islam is not based on Muslims and does not establish particular leaders in particular governments and through which system they must govern, but Islam has given us absolute freedom to organize the country according to intellectual, 
social and economic conditions that we have and take into account the social developments and demands of the time. Ar-Raziq's view separates religion and state.

Based on the Preamble of the 1945 Constitution and Article 29 paragraph (1) and (2), the Republic of Indonesia explicitly does not separate the state from religion or vice versa. Therefore, this paradigm cannot be used to explain the relationship between religion and the Republic of Indonesia.

\section{Indonesia is not a religious state}

In the Unified Paradigm, religion and state are integrated. The area of religion includes politics and the state. The state is both a political and religious institution. Therefore, according to this paradigm, the head of state is the holder of power, including political power. The government is organized based on divine sovereignty because the supporters of this paradigm believe that sovereignty is in the hands of God. This paradigm is adopted by Shia Islam (Abu al-'Ala Al-Mawdudi, 1990: 272). This politics is based on religion and functions to implement "God's Sovereignty." A people who obey the rules of the country means they obey religion. Conversely, rebelling against the state means rebelling against religion, which is also against God.

Because of its nature, western writers view religious state as incompatible with democracy. Democracy that departs from anthropocentricism views humans as the center of all things, including the center of sovereignty, so that the head of state must submit to the will and control of the people. Meanwhile, religious state originates from theocentric, making God the center of all things. The head of state is the incarnation of 
God who necessitates absolute submission without resistance. In the name of God, the ruler can do anything and ignore the people's resistance.

The theory of the union of religion and state is a theory that places a certain religion formally in a country. Because Indonesia does not formally place certain religions in state management, this theory cannot be used to analyze the relationship between religion and state in Indonesia.

\section{Indonesia is a religious state}

The relationship between religion and the Republic of Indonesia is typical and unique. Indonesia, unlike western countries, does not separate the state affairs from religion. However, Indonesia is not a religious state like the post-1979 Iranian revolution led by Imam Khomeini, or Pakistan after the military coup led by Zia Ul Haq.

The definition of the state based on belief in one Almighty God as normatively determined in Article 29 paragraph (1) refers to a religious understanding of quality, namely the quality of God. Although the Preamble of the 1945 Constitution contains the word "Allah" which refers to Islam, the text cannot be claimed only by Islam because the word is also used by Christians and Catholics. The passionate spirit to live in a nation and country as a unity is what makes the followers of the majority religions give up from claiming to be Islam. In the spirit of unity, there is a tacit consensus that the Indonesia is a religious state.

It can be said that the relationship of religion and state can be categorized as a symbiotic relationship, which means there is a reciprocity and mutual need. In this case, religion requires the state because the state can help religion to develop, and the state also needs religion as the state can 
develop in ethical and moral-spiritual guidance (M. Dien Syamsudin, 1996: $6)$.

Within the framework of this symbiotic relationship, Ibn Taymiyah in as-Siyasah ash-Syar'iyyah states that the existence of a power that regulates human affairs is the greatest religious obligation. It is because without the power of a state, religion cannot stand upright. Ibn Taymiyyah suggests that the establishment of a state is a sacred duty demanded by religion as one of the tools to bring people closer to God. In this concept, Sharia (Islamic law) occupies a central position as a source of legitimacy to political reality. Therefore, in the context of upholding Islamic law, the state has a strategic position. The state has a big role to uphold the law.

Based on this framework of understanding the symbiotic relationship between religion and state, Indonesia is a religious state, meaning that Indonesia is a country that gives place to religion in such a way that religion and the state become interdependent. The state needs religion and the religion needs the state. The relationship between religion and the state can be measured by the common interest as a state with various religions to achieve the goal of establishing the state, which is to protect people and nation of Indonesia to live in peace and social justice.

To be able to realize the purpose of personal religious life as determined by the religion for its followers and the purpose of living together in the nation and state, there should be no conflict between the purpose of personal life taught in religion with the purpose of living together in the nation and state. One area that intersects very closely between religion and state is the field of law, because religion contains norms that must be 
adhered to by its followers, while the state in regulating human life consists of religious people.

In this context, the state has a multilevel role. First, the state is constitutionally obliged to recognize and guarantee the followers of religions to worship and practice their respective religions. If desired, the state must take a role in upholding the teachings of religions believed by its followers. One area that is consciously believed by the followers of religions as inseparable from religious teachings is the field of marriage law. Thus, Article 2 paragraph (1) of Law No. 1 of 1974 on Marriage has been properly formulated, as it states that marriage is legal if done according to the respective religious law. However, the recognition of religious law for nonMuslims in Indonesia cannot be carried out properly as a legal system because it has not been made part of the national law enforcement system.

\section{B. The state of law in Indonesia: The state of religious law}

Indonesia is a state based on law of Rechtstaat, as explained in the 1945 Constitution. This term has become a debate because the notion of rechstaat refers to the notion of the rule of law as practiced in continental European countries which exclude religion from state affairs. In addition, the definition of state of law may also become an issue if it is interpreted in the framework of the rule of law, because the basis of rule of law also excludes religion from state affairs (Muhammad Tahir Azhari, 1992: 66-74).

The definition of the rule of law in the constitution must be interpreted systematically in the context of national principle, which as stated in Article 29 of the 1945 Constitution is based on belief in one Almighty God. Therefore, Indonesia is substantially not in the sense of rechstaat or the rule of law, but a 
typical and unique state of law, namely a state of law based on belief in one Almighty God, or can be called a state of religious law, or as Muhammad Tahir Azhari calls it, the Pancasila state of law (Muhammad Tahir Azhari, Ibid: 68).

The typicality or uniqueness of the concept of the rule of law based on belief in one Almighty God is the law in force in Indonesia that must not be in conflict with the teachings of a legitimate religion recognized in Indonesia. Therefore, the laws prior to independence that are enacted based on the Transitional Rules of the 1945 Constitution are constitutionally ordered to be replaced according to the demands of the development of post-independence society.

Substituting the secular law which is still enforced according to the Transitional Rules and adjusting it to religious constitution is not easy to do. It is because there are several aspects concerning legal system that must be considered, namely the issue of legal norms, the issue of law enforcement, and the issue of community legal culture.

The issue of legal norms concerning religious teachings has different levels of legal regulation in each religion. Arrangements on the same religious level can lead to differences in understanding regarding the law because of different school of belief in the religion, so it requires an in-depth study to equalize the perception of the law.

The issue of law enforcement involves law enforcement officers who are driven by rules in procedural law that is mechanical and formal. In fact, this issue has a lot to do with the way of thinking in the law and justice system that has been inherited by the law enforcement system and the former secular Dutch colonial rule. 
The issue of community legal culture concerns issues of awareness of values related to law. Because of the Dutch colonialism in which there was a rule of law, religious values were to some extent distorted by the values of secularism, so that the legal culture of religious communities was reduced to a certain degree in religious level. Non-Muslim citizens do not have a legal culture to judge according to the religion they believe. This is due to the fact that conceptually, religions other than Islam do not have a very strong normative way of thinking as is the case in Islam, so beliefs and religious teachings and their relation to law does not exist and therefore cannot be applied. Cultivating a legal culture for judging in accordance with their religions for non-Muslim communities is not easy to do.

\section{Positivization problem of religious norms regarding marriage for non- Muslim citizens}

Law Number 16 of 2019 on Amendment of Law Number 1 of 1974 on Marriage determines that marriage is legal if done according to the law of each religion. In Indonesia, there are 6 religions that are officially recognized by the state, namely Islam, Christianity, Catholicism, Hinduism, Buddhism and Confucianism. It means that the material law regarding marriage applied in Indonesia is the marriage law governed according to religion which is embraced by people in Indonesia. The positivization of religious law into positive law means that;

a. The marriage law that applies to Muslims is a law based on Islamic law.

b. The marriage law that applies to Catholics is a law based on Catholicism. 
c. The marriage law that applies to Christians is a law based on Christianity.

d. The marriage law that applies to Hindus is a law based on Hinduism.

e. The marriage law that applies to Buddhists is law based on Buddhism.

f. The marriage law that applies to Confucians is a law based on Confucianism.

In terms of legal system, marriage law concerns issues related to the legal requirements of marriage, elements of marriage, divorce, legal consequences of marriage such as those concerning living, children and everything related to marriage, including its relationship to inheritance. However, in reality, this positivity is still artificial. It is because religious norms that have been stated as positive law for religion adherents are only used by non-Muslim citizens when conducting marriages only. Issues in dispute which are related to legal consequences of marriage carried out based on religious law, either directly or indirectly, are not resolved based on the respective religious laws. It means that the state does not enforce the marriage legal system for non-Muslims as it is enforced for Muslims.

The non-enforcement of marriage law based on religion for non-Muslims as it is enforced for Muslims is legally explained systematically.

a. Constitutional factors

The written constitution of the Republic of Indonesia as contained in Article 29 paragraph (1) of the 1945 Constitution stipulates that the state is based on belief in one Almighty God. If it is traced from a long history of struggles for independence, the drafting of written constitution, and the process of enacting the 1945 Constitution, the term "Almighty God" 
refers to religion, namely religions which are the beliefs of Indonesian citizens.

By not specifically mentioning certain religions, it shows that the term "state based on belief in one Almighty God" means that (1) the state is based on religions that are believed by Indonesian citizens, so every state policies represented by the government must be in accordance with and not contrary to the teachings of the religions of Indonesian people; (2) the state is neutral in regulating policies relating to religion; (3) the state does not have a basis in power to enforce religious teachings, so Article 29 paragraph (2) of the 1945 Constitution stipulates that the country guarantees the independence of each resident to embrace their respective religions and to worship according to their religion and belief. Based on Article 29 paragraph (2), it can be taken into account that the state is obliged to recognize what is believed by the people concerning their religion. Therefore, constitutionally, the state does not have the right directly to use religious law in the process of resolving disputes relating to marriage in the District Court.

b. Cultural factors

Each scripture believed by its followers has a teaching concept about marriage. The concept of marriage has different intensity in different religions, but there are norms about marriage in every one of them.

Understanding of religious teachings about marriage mostly depends on the religious leaders. They have a great influence on religious understanding, but their explanation about the concept of marriage are 
not as clear as the other religious rituals. Therefore, the understanding about marriage is not as strong as the understanding about other religious rituals.

Christianity and Catholicism have a relatively strong normative system, but Western and American countries, in which there is a majority of Christians and Catholics, apply the principle of secularism. Religion is excluded from state affairs. Religion is localized only as a private matter of those who believe in their God. As a result, Christians and Catholics tend to think weakly about religious law. Nevertheless, Catholicism is still able to maintain its religious law internally within the church, though outside the authority of the state. Meanwhile, Christianity is in a position that is unable to defend its religious legal thinking, so religious law in the church is not internally applied. In the field of law, secularism teaches the separation of law from religion. This way of thinking is the characteristic of the modern world. The current of secularization that separates law from religion is prevalent throughout the world (Robert W Hafner, 2001: 33).

Actually Catholics and Christians in Indonesia live in a country that is not secular. This is very much realized, as the level of religiosity of Christians and Catholics in Indonesia is higher than Christians and Catholics living in Europe and the United States. It leads to Christian and Catholic missionaries in the world being taken from Indonesian people. It means that there is a common thread between the religious state of Indonesia and the religiosity of Christians and Catholics in Indonesia.

Even so, Indonesia which is constitutionally religious has not been able to awaken religiosity in the field of law. Christians and Catholics in 
Indonesia do not have strong legal ideas up to the level of imposing marriage law taught in their religion at the state level. It is proven by the fact that the right granted by the constitution and the Law to demand the enactment of the marriage law based on religion is not used (Theodorus Y. Parera and Bernard L. Tanya, 2018: 37).

Hinduism, Buddhism and Confucianism are classified in literatures as cultural religions, which means religions that are more characterized by tradition, so they do not have a strong normative system. Therefore, although it is believed that in these three religions there are teachings about marriage, but the religious teaching system is such that it makes its followers cannot have strong thinking about the law based on the religion they believe.

Thus, although the five religions (Christian, Catholic, Hinduism, Buddhism, and Confucianism) have different levels of normative systems and legal thinking, they are commonly on the same level of having the lack of legal thinking related to the religion they believe. Therefore, nonMuslim citizens officially do not have the awareness to demand the state to make their religious teachings about marriage a positive law that can be used by judges to examine, adjudicate, and decide cases in court.

c. Structural factors

Structural area is formal procedural area, an area that limits itself to non-substantial requirements. The problem with the positivization of religious norms about marriage is a substantial and highly philosophical legal problem. In the absence of formal procedural rules instructing law and justice enforcement to enter the substantial territory, a judge has no 
way to enter the territory. Law and justice enforcement agencies cannot enter substantial territory if they are not instructed to do so. Therefore, in carrying out state duties in examining, adjudicating, and deciding cases, a judge is strictly regulated in procedural law.

The legal logic of judges as legal practitioners is bound by a strongly positive system. Moreover, the legal system in Indonesia is based on Civil law, which makes judges unable to improvise in examining, adjudicating, and deciding cases. Their normative logic dominates their way of thinking, so the legal logic is always concrete. This condition motivates the judge in examining cases, especially the ones related to marriage. In this case, judges cannot involve philosophical issues.

In their interpretation of Article 2 paragraph (1), which states that the validity of a marriage is carried out according to the respective religious law, a judge only has the understanding that the authority to adjudicate disputes relating to marriage for persons other than Islam is held by the District Court. This interpretation is very pragmatic. The judge does not want to involve an abstract issue while examining marital cases, so they never consider the connection between the case and the religion believed by the disputing parties. The religious belief of the disputing parties are completely absent from the judge's perspective. The legal logic of the judge only considers concrete things that actually exist and occur, without thinking about what should be done according to religion. The conviction about justice in the examined and decided cases does not reach the level of the power of the Almighty God. Philosophical thinking is only possible if it has explicitly become a positive rule, both in the form of procedural formal rules and substantial normative rules. 


\section{Conclusion}

It is a fact that the Dutch does not only colonized Indonesia economically, but also legally. Various policies were made to get rid of the original Indonesian law which was religious in nature to force the Dutch law that is secular. As a result, legal logic, concepts, and theories of Western law, especially the Netherlands, which are based on the ideology of secularism, dominate the way of thinking about law in Indonesia.

Independence is a new milestone to show the existence of the nation, with the 1945 Constitution as an identity that expressively states that the country is not secular. However, because of the strong grip of the colonialism of law, the logic, concepts, theories, institutions, and enforcement of Dutch law still dominate Indonesian law. Therefore, non-secularization of marriage law for non-Muslims carried out by Law Number 16 of 2019 on Amendment of Law Number 1 of 1974 on Marriage cannot be implemented because the right of nonMuslim citizens to demand the enactment of marriage law guaranteed by the constitution are not applied. 


\section{BIBLIOGRAPHY:}

\section{Books:}

Ali, M. D. (2002). Hukum Islam, Pengantar Hukum Islam dan Tata Hukum Islam di Indonesia. Jakarta: Rajawali Press.

Al-Mawdudi, A. a.-A. (1990). Khilafah dan Kerajaan. (M. Al Baqir, Trans.) Bandung: Mizan.

Azhari, M. T. (1992). Negara Hukum, studi tentang prinsip-prinsipnya dilihat dari segi hukum Islam, Implementasinya pada Periode negara Madinah. Jakarta: Bulan Bintang.

Hafner, R. W. (2001). Islam di Era negara bangsa, kebangkitan Politik dan Agama Muslim di Asia Tenggara. (I. Rasyidi, Trans.) Yogyakarta: Tiara Wacana.

Parera, T. Y., \& Tanya, B. L. (2018). Panorama Hukum dan Ilmu Hukum. Yogyakarta: Genta Publishing.

Piscatory, J. P. (1983). Islam in the Political Process. New York: Cambridge University Press.

Qadir, Y. (2007). Islam Syariat vis a vis Negara. Yogyakarta: Pustaka Pelajar.

Syadzali, M. (1990). Islam dan tata negara. Jakarta: UI Press.

Syamsudin, M. D. (1996). Usaha Pencarian. Cirebon: Jilli.

Taha, M. M. (1996). Second Message of Islam: Syariah Demokratik. Surabaya: eLSAD.

Wahid, M., \& Rumadi. (2001). Fiqh Madzab Negara. Yogyakarta: LKIS.

Gumbira, S. W., Handayani, I. G. A. K. R., \& Tedjomurti, K. T. (2019). The

Urgency of Presidential Policy to Revitalize and Maintain the Existence of Cooperatives Based on Pancasila. Sriwijaya Law Review, 3(2), 199-224.

\section{Legal Documents:}

1945 Constitution of The Republic of Indonesia

Law Number 16 of 2019 on Amendment of Law Number 1 of 1974 on Marriage 